ERIA - DP - 2009- 22

ERIA Discussion Paper Series

\title{
Who Uses Free Trade Agreements?
}

\author{
Kazunobu HAYAKAWA ${ }^{\# \S}$ \\ Institute of Developing Economies, Japan External Trade Organization, Japan \\ Daisuke HIRATSUKA \\ Institute of Developing Economies, Japan External Trade Organization, Japan \\ Kohei SHIINO \\ Overseas Research Department, Japan External Trade Organization, Japan \\ Seiya SUKEGAWA \\ Overseas Research Department, Japan External Trade Organization, Japan
}

November 2009

\begin{abstract}
It is noted that utilization of ASEAN Free Trade Agreements (FTAs) is low by international standards. In order to clarify the reasons for such low utilization, this paper investigates what kinds of Japanese affiliates in ASEAN are more likely to use FTAs in their exporting, by employing unique affiliate-level data. Our findings are as follows. First, the larger the affiliate is, or the more diversified the origins of its procurements, the more likely it is to utilize an FTA scheme in its exporting. Second, affiliates that export actively to countries with higher general tariffs are more likely to use FTAs. Third, there are clear differences in FTA utilization depending affiliates' locations and sectors.
\end{abstract}

Keywords: FTA; micro data; ASEAN

JEL Classification: F15; F53; O53

\footnotetext{
\# Corresponding author: Kazunobu Hayakawa. Address: Economic Integration Studies Group, Inter-Disciplinary Studies Center, Institute of Developing Economies, 3-2-2 Wakaba, Mihama-ku, Chiba-shi, Chiba 261-8545 Japan. Phone: 81-43-299-9754; Fax: 81-43-299-9763. E-mail: kazunobu_hayakawa@ide.go.jp.

$\S$ This research was conducted as a part of the project of the Economic Research Institute for ASEAN and East Asia (ERIA) known as "Deepening East Asian Economic Integration." We thank Hidehiro Ishiura and Mitsutoshi Okabe for their arrangement of the micro data used in this study. We also thank Fukunari Kimura, Archanun Kohpaiboon, Toshiyuki Matsuura, So Umezaki for their invaluable comments. The opinions expressed in this paper are the sole responsibility of the authors and do not reflect the views of ERIA or the Japan External Trade Organization.
} 


\section{Introduction}

Free Trade Agreements (FTAs) have proliferated in East Asia. Currently, there are more than thirty Regional Trade Agreements (RTAs) in force involving East Asia, of which fourteen are intra-regional. Regionalism in East Asia has been led by ASEAN in particular; the ASEAN Free Trade Area (AFTA) is an agreement that will eliminate import duties on all products placed in the normal track in the ASEAN-6 (Brunei, Indonesia, Malaysia, the Philippines, Singapore, and Thailand). The new member countries, Cambodia, Laos, Myanmar, and Vietnam, will also eliminate tariffs in the normal track by 2015. Furthermore, regionalism in the ASEAN+6 regions is exacerbating the hub-and-spoke FTA structure with ASEAN as the hub and other East Asian countries as the spokes. ${ }^{1}$

However, such proliferation does not automatically increase the number of international transactions that utilize FTA schemes. In reality, all firms do not necessarily use an FTA scheme in their exporting or importing. Administrative costs for securing certificates of origin (COO), which certify that the exported goods were locally produced, play a key role in firms' choice to use FTAs. In order to secure the COO for the goods they export, firms must prepare all documents required by the investigating authorities. Since such document preparation is counted as fixed costs, only firms that earn operating profits enough to cover the fixed costs will choose to use an FTA scheme. In East Asia, the optional criterion or change in tariff classification criterion tend to be adopted as criteria to determine the origin of goods, the so-called rules of origin (ROO). ${ }^{2}$ The

\footnotetext{
${ }^{1}$ In this paper, FTA, RTA, and Economic Partnership Agreement (EPA) are used interchangeably.

2 There are four main types of criteria to determine the origin of goods: 1) the value-added content criterion, 2) the change in tariff classification criterion, 3) the optional criterion that allows firms a
} 
"third-party certificate system" is often adopted as a procedure to certify origin; this is a system wherein third parties such as a relevant ministry or a chamber of commerce take a role in issuing a certificate of origin after reviewing applications filed by firms. ${ }^{3}$ In East Asia, such ROO and procedures to certify origin result in a certain amount of fixed costs for FTA use, discouraging firms from utilizing an FTA scheme.

Particularly in East Asia, it is noted that the rate of FTA utilization remains at a fairly low level. Hiratsuka et al. (2008) point out that, to begin with, Japanese firms and their affiliates operating in ASEAN are not well aware of FTAs. The utilization of AFTA measured by the ratio of AFTA administrative records to total exports was low, at around $15 \%$ to $20 \%$, during the period $2003-06$. The utilization rate on the import side was around $11 \%$ to $16 \%$, lower than the corresponding rate for the export side. Furthermore, the utilization of AFTA observed for both exports and imports is low by international standards. Kohpaiboon (2008) pointed out that the AFTA utilization rates were lower than those of NAFTA; the NAFTA utilization rate by Mexican exports to the United States was around $60 \%$ in $2004-05$. The utilization rate by Chilean exports to the United States was around 55\% in 2005-06 (James, 2006).

Against this backdrop, the aim of this paper is to clarify the reasons for the low rate of FTA utilization in East Asia by investigating what kinds of Japanese affiliates in ASEAN are more likely to use FTAs in their exporting. Indeed, such firm characteristics have potentially important policy implication, but they remain almost unknown. From the theoretical point of view, we can refer to one important paper, Demidova and Krishna

choice of whether to use the value-added content criterion or the change in tariff classification criterion, and 4) the dual criterion which requires firms to use both the value-added content criterion and the change in tariff classification criterion. For details of each criterion, see the WTO website.

${ }^{3}$ There are three main procedures to certify the origin of goods: 1) the third-party certificate system, 2) the self-certificate system, and 3) a hybrid system of third-party certification and self-certification. For details of each system, see the WTO website. 
(2008). Introducing firm heterogeneity as in Melitz (2003), they demonstrate that productive firms use an FTA scheme in their exporting, while the less productive firms use general tariff rates because the less productive firms cannot afford to pay document fixed costs for FTA use. Thus, firms' productivity can be taken as one important firms' attribute. Also on the empirical side, there are few previous studies investigating such firms' attributes, perhaps due to the limited data. ${ }^{4}$ Nevertheless, there are three important trial papers. Kohpaiboon (2008) analyzed AFTA implementation by Thai exporters for the period 2003-06, by using AFTA administrative records (collected by the Bureau of Preferential Trade, Department of Foreign Trade, Ministry of Commerce). He found that large conglomerate firms or firms in industries with a huge margin between general and preferential tariff rates tend to utilize the AFTA scheme. If we take firms' scale as a proxy for their productivity, the former result supports the above-mentioned theoretical proposition in Demidova and Krishna (2008) at the sector level. On the other hand, Takahashi and Urata $(2008,2009)$ examine FTA usage by Japanese firms at the firm level by employing a questionnaire survey. They found that larger firms are more likely to use FTA schemes. Thus, the positive relationship between a firm's productivity and its FTA use is valid also at the firm level.

In this paper, we employ a unique dataset. The Japan External Trade Organization (JETRO) has carried out an ongoing survey of Japanese affiliates operating in Asia for 22 years, since 1987. The survey was initially targeted at manufacturing companies, but in the wake of the growth of the service sector, inclusion of non-manufacturing companies began in 2007 (the 21st survey). The survey, named the "Survey of Japanese-Affiliated Firms in ASEAN, India, and Oceania," has included questions on the affiliates' FTA use

\footnotetext{
${ }^{4}$ The impact of FTA on trade is often evaluated by estimating the well-known gravity equation. See, for example, Endoh (1999) and Baier and Bergstrand (2007).
} 
particularly in the last three years. For example, it asks whether or not the affiliate currently uses any existing bilateral/multilateral FTAs or EPAs for import or export activities. In the survey, moreover, the basic information on affiliates' activities, such as the breakdown of their export destinations and their procurement sources, is also collected. Therefore, this survey enables us to explore more firm characteristics including their scale. In addition, using the detailed firm characteristics, we can examine firms' choice of FTA use with the more sophisticated sample. For example, it is possible to restrict the sample to firms which are actually exporting to FTA partner countries. Such detailed and sophisticated analyses will contribute to the enhancement of our understanding of the mechanics of firms' FTA use.

The organization of this paper is as follows. Section 2 introduces our dataset and presents an overview of Japanese affiliates' FTA use in Asia. In Section 3, we present our hypotheses on the relationship between firms' characteristics and their FTA use. Our empirical framework for examining such hypotheses is presented in Section 4. The empirical results are reported in Section 5, and our conclusion is presented in Section 6.

\section{The Utilization of FTAs by Japanese Affiliates}

Employing the $22^{\text {nd }}$ JETRO survey, this section introduces the usage of FTAs by Japanese affiliates. The survey, which was sent to 5,107 Japanese affiliates operating in thirteen countries, received 1,852 valid responses (36.3\%). Of these, 1,354 were from ASEAN7 countries (Thailand, Malaysia, Singapore, Indonesia, the Philippines, Vietnam, and Myanmar), 235 from South Asia (India, Bangladesh, Pakistan, and Sri Lanka), and 
263 from Oceania (Australia and New Zealand). Although our main analysis presented in the following sections is devoted to the usage of FTAs for exporting in ASEAN, this section also refers, for the sake of completeness, to the usage of FTAs for importing in ASEAN. In order to ensure sufficient responses in each ASEAN country, we focus on six ASEAN countries (Indonesia, Malaysia, the Philippines, Singapore, Thailand, and Vietnam).

Table 1 reports Japanese affiliates' usage rates of FTAs in their exporting and importing by their location. Here we restrict our sample to Japanese affiliates that are actually exporting to or importing from any countries. From this table, we can see that $22 \%$ of Japanese affiliates with export operations in ASEAN take advantage of FTAs. This ratio is much lower than $60 \%$ in Mexican exports to the United States and $55 \%$ in Chilean exports to the United States. Taking a closer look at FTA usage by location in ASEAN, the highest level of FTA usage is in Singapore (35\%), followed by Indonesia (26\%), and Malaysia (25\%). In contrast, in the Philippines and Vietnam, the ratio is around $10 \%$. Turning to imports, $18 \%$ of Japanese affiliates with import operations in ASEAN utilize FTAs for imports, slightly less than the $22 \%$ for exports. In sum, the FTA utilization ratio in Japanese affiliates is quite low. 
Table 1. Utilization of FTAs

\begin{tabular}{cccccccc}
\hline \hline & \multicolumn{3}{c}{ Exporter } & & \multicolumn{3}{c}{ Importer } \\
\cline { 2 - 3 } \cline { 6 - 8 } & Use & $\begin{array}{c}\text { Intend } \\
\text { to use }\end{array}$ & $\begin{array}{c}\text { No intention } \\
\text { to use }\end{array}$ & & Use & $\begin{array}{c}\text { Intend } \\
\text { to use }\end{array}$ & $\begin{array}{c}\text { No intention } \\
\text { to use }\end{array}$ \\
\hline ASEAN & $22 \%$ & $28 \%$ & $50 \%$ & & $18 \%$ & $27 \%$ & $55 \%$ \\
Indonesia & $26 \%$ & $35 \%$ & $39 \%$ & & $24 \%$ & $37 \%$ & $39 \%$ \\
Malaysia & $25 \%$ & $21 \%$ & $53 \%$ & & $16 \%$ & $18 \%$ & $66 \%$ \\
Philippines & $15 \%$ & $23 \%$ & $61 \%$ & & $10 \%$ & $20 \%$ & $70 \%$ \\
Singapore & $35 \%$ & $22 \%$ & $44 \%$ & & & & \\
Thailand & $22 \%$ & $34 \%$ & $44 \%$ & & $21 \%$ & $33 \%$ & $46 \%$ \\
Vietnam & $9 \%$ & $28 \%$ & $62 \%$ & & $14 \%$ & $28 \%$ & $59 \%$ \\
\hline \hline
\end{tabular}

Source: Survey of Japanese-Affiliated Firms in ASEAN, India, and Oceania.

Note: "Use" refers to the share of affiliates that are already using FTAs, "Intend to use" to the share of affiliates that are now not using but are considering the use of FTAs, and "No intention to use" to the share of affiliates that are now not using and are not going to use FTAs. The figures in Singaporean imports are not available since the general tariff rates are already zero or quite low in Singapore.

The JETRO survey also asks firms about their reasons for not utilizing FTAs/EPAs.

The leading reason in the case of exporting is that "importers are exempted from tariffs" (123 firms, 37.6\%). Actually in many ASEAN countries, incentives to promote inbound investment reduce or eliminate tariffs on materials or parts imported for assembly and exported as finished products. Thus, if firms export to countries with such incentives, they do not need to make use of FTAs/EPAs in their exporting. The second reason is that "there are no FTAs/EPAs with the countries to which we export" (75 firms, 22.9\%). ${ }^{5}$ On the other hand, the leading reason why FTAs are neither employed nor considered in importing is that investment incentive schemes have already eliminated tariffs, as in the case of exporting (157 firms, 48.9\%). Other reasons mentioned include "low levies on products sold domestically" (13.4\%) and "no FTAs/EPAs with the countries from which we import" (13.1\%).

\footnotetext{
5 The third reason is that "tariffs are already low in the countries to which we export" ( 65 firms, 19.9\%). Indeed, of the 390 manufacturing firms in Asia and Oceania, the largest proportion (28.2\%) state that they would consider using an FTA with a preferential tariff margin in the 3\% to 5\% range (according to the 22nd Survey of Japanese-Affiliated Firms in ASEAN, India, and Oceania).
} 
As a result, the low utilization ratio of Japanese affiliates in ASEAN relates partly to their trading with partner countries that do not conclude FTAs with the host countries and partly to the existence of investment incentive schemes. One may say that the non-FTA using affiliates in the former case should be eliminated from our sample in calculating FTA utilization ratios. The results excluding such affiliates are reported in Table 2. We can see that FTA utilization ratios rise slightly in most of the countries. For example, in ASEAN, those ratios increase from $22 \%$ to $27 \%$ in exporting and from $18 \%$ to $23 \%$ in importing. In addition, it might be valuable to calculate FTA utilization ratios after eliminating affiliates not only in the former case but also in the latter case. Such utilization ratios are reported in Table 3. Compared with Table 2, all countries experience a slight rise in FTA utilization ratios, which in ASEAN turn out to be $33 \%$ in exporting and $31 \%$ in importing. However, we can still say that FTA utilization in ASEAN is much lower than that in other regions, as mentioned in the introductory section.

Table 2. Modified Utilization of FTAs

\begin{tabular}{cccccccc}
\hline \hline & \multicolumn{3}{c}{ Exporter } & & \multicolumn{3}{c}{ Importer } \\
\cline { 2 - 3 } \cline { 6 - 8 } & Use & $\begin{array}{c}\text { Intend } \\
\text { to use }\end{array}$ & $\begin{array}{c}\text { No intention } \\
\text { to use }\end{array}$ & & Use & $\begin{array}{c}\text { Intend } \\
\text { to use }\end{array}$ & $\begin{array}{c}\text { No intention } \\
\text { to use }\end{array}$ \\
\hline ASEAN & $27 \%$ & $27 \%$ & $46 \%$ & & $23 \%$ & $27 \%$ & $50 \%$ \\
Indonesia & $43 \%$ & $22 \%$ & $35 \%$ & & $33 \%$ & $34 \%$ & $33 \%$ \\
Malaysia & $26 \%$ & $19 \%$ & $55 \%$ & & $20 \%$ & $21 \%$ & $59 \%$ \\
Philippines & $14 \%$ & $29 \%$ & $57 \%$ & & $8 \%$ & $21 \%$ & $71 \%$ \\
Singapore & $46 \%$ & $17 \%$ & $37 \%$ & & & & \\
Thailand & $26 \%$ & $31 \%$ & $43 \%$ & & $28 \%$ & $29 \%$ & $43 \%$ \\
Vietnam & $12 \%$ & $35 \%$ & $53 \%$ & & $14 \%$ & $28 \%$ & $58 \%$ \\
\hline \hline
\end{tabular}

Source: Survey of Japanese-Affiliated Firms in ASEAN, India, and Oceania.

Notes: In this table, we exclude affiliates trading to countries without any FTAs with the host country. "Use" refers to the share of affiliates that are already using FTAs, "Intend to use" to the share of affiliates that are now not using but are considering the use of FTAs, and "No intention to use" to the share of affiliates that are now not using and are not going to use FTAs. The figures in Singaporean imports are not available since the general tariff rates are already zero or quite low in Singapore. 
Table 3. Further Modified Utilization of FTAs

\begin{tabular}{cccccccc}
\hline \hline & \multicolumn{3}{c}{ Exporter } & & \multicolumn{2}{c}{ Importer } \\
\cline { 2 - 3 } \cline { 6 - 7 } & Use & $\begin{array}{c}\text { Intend } \\
\text { to use }\end{array}$ & $\begin{array}{c}\text { No intention } \\
\text { to use }\end{array}$ & & Use & $\begin{array}{c}\text { Intend } \\
\text { to use }\end{array}$ & $\begin{array}{c}\text { No intention } \\
\text { to use }\end{array}$ \\
\hline ASEAN & $33 \%$ & $33 \%$ & $33 \%$ & & $31 \%$ & $37 \%$ & $32 \%$ \\
Indonesia & $50 \%$ & $26 \%$ & $24 \%$ & & $38 \%$ & $39 \%$ & $24 \%$ \\
Malaysia & $38 \%$ & $28 \%$ & $34 \%$ & & $28 \%$ & $29 \%$ & $43 \%$ \\
Philippines & $18 \%$ & $36 \%$ & $45 \%$ & & $15 \%$ & $39 \%$ & $46 \%$ \\
Singapore & $54 \%$ & $20 \%$ & $26 \%$ & & & & $24 \%$ \\
Thailand & $31 \%$ & $36 \%$ & $33 \%$ & & $37 \%$ & $39 \%$ & $31 \%$ \\
Vietnam & $16 \%$ & $46 \%$ & $38 \%$ & & $23 \%$ & $46 \%$ & 30 \\
\hline \hline
\end{tabular}

Source: Survey of Japanese-Affiliated Firms in ASEAN, India, and Oceania.

Notes: In this table, we further exclude importers enjoying investment incentive schemes or exporters of which trading partners enjoy such schemes. "Use" refers to the share of affiliates that are already using FTAs, "Intend to use" to the share of affiliates that are now not using but are considering the use of FTAs, and "No intention to use" to the share of affiliates that are now not using and are not going to use FTAs. The figures in Singaporean imports are not available since the general tariff rates are already zero or quite low in Singapore.

\section{Hypotheses}

This section presents our hypotheses, which are empirically tested in the following sections, on what kinds of firms use an FTA scheme in their exporting. For firms to use an FTA in exporting, the total profit (= operating profit minus fixed costs) from using the FTA must be greater than that from not using it. If firms choose to use an FTA scheme, then they can export their products with the FTA preferential tariff rates, which are mostly zero percent. Otherwise, they must pay the general tariff rates, which are mostly most-favored nation rates (MFN rates). Use of the FTA scheme, however, will incur a certain level of administrative cost as mentioned in the introductory section, which becomes an additional fixed cost for the firms. Therefore, for firms to use FTAs, it is 
necessary that the difference in the operating profit using FTA rates and operating profit using general tariff rates is greater than the fixed costs of FTA use.

This argument leads immediately to that the larger the difference between FTA rates and general tariff rates, the larger the difference in the operating profits from using them. Since the FTA preferential rates are mostly zero, it might be simply said that the higher the general tariff rates, the larger the difference in the operating profit. As a result, we have the following testable hypothesis:

- Hypothesis 1. Firms that export to countries with lower general tariff rates are less likely to use FTAs.

The empirical validity of this hypothesis is just confirmed by Kohpaiboon (2008) at the sector level.

On the other hand, even if the tariff margin between them is not so large, the larger the volume of exports, the larger the difference in the operating profit per se would be. This implies that any elements affecting a firm's volume of exports and thus its volume of outputs are also important. For example, since lower wages lead to larger outputs, firms in countries with low wages can obtain a greater difference in the operating profit between two tariff rates and are likely to cover fixed costs for FTA use. Particularly in this paper, we examine the following two firm specific elements.

The first one is firms' productivity. As mentioned in Section 1, it is expected that the more productive firms are more likely to use FTAs in their exporting (Demidova and Krishna, 2008). Also in our context, since a firm's outputs are increasing in proportion to its productivity, the difference in the operating profit between FTA rates and general tariff rates is positively related to the firm's productivity. Therefore, firms with higher 
productivity can afford to pay administrative costs and are thus more likely to use an FTA scheme. As a result, the testable hypothesis on productivity can be summarized as:

- Hypothesis 2. The more productive firms are more likely to use FTAs in their exporting.

The second element sheds light on a firm's diversity in its sources of procurements. The hypothesis is summarized as:

- Hypothesis 3. The more diversified the origins of firms' procurements are, the more likely the firms are to use FTAs in their exporting.

This is the well-known love-of-variety nature in the procurement of intermediate products. Suppose that intermediate products are differentiated, and further, that firms prefer more varieties of intermediate products, as in the usual new trade theory; the more diversified origins of firms' procurements lowers their input costs, resulting in a larger volume of output. In addition to this benefit from the horizontal nature of procurement, its diversified origins may yield benefits from vertical division of labor, i.e., international fragmentation. ${ }^{6}$ That is, input costs are lowered by sourcing each intermediate product from a country with location advantages in producing it. In sum, the more diversified the origins of firms' procurements are, the larger their outputs/exports are, and thus the larger the difference in the operating profit between FTA rates and general rates.

However, more diversified origins might substantially raise the administrative costs for FTA use. In certifying that the exported goods were locally produced, exporters must prepare a list of materials inputted for producing them. To complete the list, exporters

\footnotetext{
${ }^{6}$ For a theoretical analysis of international fragmentation, see Arndt and Kierzkowski (2001). For an empirical investigation on fragmentation in East Asia, see Kimura (2006).
} 
need to request each materials supplier to issue an invoice or contract documents. Thus, higher document preparation costs are obviously entailed in sourcing materials from a larger number of suppliers. In other words, more highly diversified origins of procurements lead to larger fixed costs for FTA use. As a result, if the effect of increase of the difference in the operating profit between two tariffs is greater than the effect of a rise of fixed costs, a firm's diversity in the sources of procurement encourages it to utilize an FTA scheme. In the sense that the diversity of procurement origins has conflicting effects on firm's choice of FTA use, its empirical examination becomes important.

\section{Empirical Framework}

This section explains the methodology used to investigate the three hypotheses presented in the previous section. The source of our data for estimation, as noted in Section 2, is the "Survey of Japanese-Affiliated Firms in ASEAN, India, and Oceania" for 2006, 2007, and 2008. We again focus on Japanese affiliates in six ASEAN countries (Indonesia, Malaysia, the Philippines, Singapore, Thailand, and Vietnam). We restrict our sample only to exporting affiliates because affiliates are unable to use FTA if they do not export. ${ }^{7}$

For our empirical analysis, we specify our index function as:

$$
\Gamma_{i}=\mathbf{x}_{i}^{\prime} \boldsymbol{\beta}_{\mathbf{0}}+\varepsilon_{i} \text {, where } \varepsilon_{i} \sim N(0,1) \text { and } \mathbf{x}_{i}=\left(\text { Export }_{i}, \text { Scale }_{i}, \text { Variance }_{i}\right)
$$

$\Gamma_{i}$ is the difference in affiliate $i$ 's total profits when comparing cases of FTA use and

\footnotetext{
${ }^{7}$ We also conduct some data cleaning. For example, we eliminate observations in which the sum of export shares plus the share of the supply to the local market exceeds $100 \%$.
} 
non-use (a time script is omitted). The observation rule for affiliate $i$ is formalized as:

$$
y_{i}=\left\{\begin{array}{lll}
0 & \text { if } & \Gamma_{i} \leq 0 \\
1 & \text { if } & \Gamma_{i}>0
\end{array}\right.
$$

where $y_{j}$ is an indicator variable taking unity if affiliate $j$ uses an FTA scheme in exporting and zero otherwise. As a result, our probability model by the probit is given by:

$$
\operatorname{Pr}\left(y_{i}=1 \mid \mathbf{x}_{i}\right)=\Phi\left(\mathbf{x}_{i}^{\prime} \boldsymbol{\beta}\right)
$$

where $\Phi(\bullet)$ is the standard cumulative normal probability distribution. From our sample, we exclude the affiliates that answered "considering use" for the data item of FTA use in exporting because of their ambiguous standpoint in the choice of FTA use.

We introduce three kinds of affiliate characteristic variables. First, we examine the impact of the margin between FTA and general tariff rates in the countries to which affiliates export their products (Hypothesis 1). To this end, three kinds of FTAs in which a significant number of ASEAN countries are included as members are taken into consideration: AFTA, ASEAN-China FTA, and bilateral FTAs with Japan. Specifically, we introduce an Export vector, of which the elements are an export share to the other ASEAN countries (ExASEAN), that to China (ExCHINA), and that to Japan (ExJAPAN), in total sales. All other things being equal, as argued in the previous section, the larger exports to any countries with FTAs with host countries always increase the difference in the operating profit between FTA and general tariff rates. Thus, three share variables are expected to be significantly positive. However, the magnitude of the coefficients would differ according to differences in general tariff rates among ASEAN, China, and Japan. For example, since general tariff rates are already low in Japan and still high in China, affiliates exporting mainly to Japan would be less likely to use an FTA scheme than those 
exporting to China. As a result, the magnitude of the coefficients in descending order is expected to be ExCHINA, ExASEAN, and ExJAPAN.

Second, we examine Hypothesis 2 by introducing $\mathrm{Scale}_{i}$, which is a log of total employment. Our dataset does not have any convincing productivity measures, e.g., Total Factor Productivity (TFP) or labor productivity. From the theoretical point of view, firms' productivity is not necessarily related positively to their employment; however, from the empirical point of view, the productivity (TFP) usually has a positive correlation with the total employment (see, for example, Fukao and Kwon, 2006). Thus, the use of employment as a proxy for productivity may be plausible to some extent. As a result, the larger the affiliates' scale, the more likely they would be to utilize an FTA scheme.

Next, in order to explore Hypothesis 3, we introduce Concentration ${ }_{i}$, which captures the concentration of sources of intermediate inputs. Our dataset has the shares of local procurement, imports from other ASEAN countries, imports from Japan, imports from other Asian countries excluding ASEAN and Japan, imports from the US, imports from

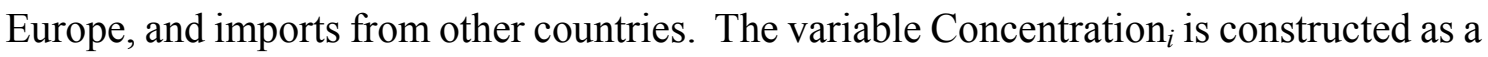
variance among the above seven shares. The lower the Concentration ${ }_{i}$, the more diversified the sources of intermediate inputs. Thus, if the love-of-variety nature of intermediate products and the benefits from vertical division of labor reduce affiliates' input costs greatly, the coefficient for Concentration $_{i}$ would be expected to be significantly negative. ${ }^{8}$ On the other hand, if the diversified sources of inputs result in a remarkable rise in the administrative costs for FTA use, its coefficient may be estimated to be positive.

So far, we have not taken care of the ROO explicitly. As mentioned before, for the

\footnotetext{
${ }^{8}$ As mentioned in Section 1, since the change in tariff classification is available as ROO in East Asia, firms do not necessarily need to source a significant share of total inputs from local producers.
} 
sake of FTA use, affiliates must secure the ROO of their goods. In order to control the extent of restrictiveness of ROO, we introduce both country fixed effects and sector fixed effects because the ROO differs according not only to FTAs but also to sectors. Several other elements are also controlled by such fixed effects, such as differences in wages among countries, which affect firms' operating profits. The differences in efficiency in obtaining the $\mathrm{COO}$ among countries are also captured by the estimates of the fixed effects. Moreover, those may include the differences in general tariff rates among sectors.

\section{Empirical Results}

In this section, we report the results of our empirical analyses. Basic statistics are provided in Table 4, and our probit results are presented in Table 5. The column (I) in Table 5 shows our baseline result (marginal effects), which is basically consistent with our expectations.

Table 4. Basic Statistics

\begin{tabular}{l|c|c|c|c|c}
\hline \hline Variable & Obs & Mean & Std. Dev. & Min & Max \\
\hline FTA & 872 & 0.282 & 0.450 & 0 & 1 \\
Scale & 872 & 5.349 & 1.426 & 1.099 & 11.608 \\
Concentration & 872 & 0.060 & 0.028 & 0.007 & 0.109 \\
ExASEAN & 872 & 0.129 & 0.206 & 0 & 1 \\
ExCHINA & 872 & 0.032 & 0.103 & 0 & 1 \\
ExJAPAN & 872 & 0.265 & 0.347 & 0 & 1 \\
\hline \hline
\end{tabular}


Table 5. Probit Results

\begin{tabular}{l|c|c}
\hline \hline & $(\mathrm{I})$ & $(\mathrm{II})$ \\
\hline Scale & $0.056^{* * *}$ & $0.169^{* * *}$ \\
& {$[0.013]$} & {$[0.040]$} \\
\hline Concentration & $-2.309 * * *$ & $-7.420^{* * *}$ \\
& {$[0.610]$} & {$[1.942]$} \\
\hline ExASEAN & $0.195 * *$ & $0.632^{* *}$ \\
& {$[0.080]$} & {$[0.251]$} \\
\hline ExCHINA & $0.324 *$ & $1.018 * *$ \\
& {$[0.139]$} & {$[0.437]$} \\
\hline ExJAPAN & $0.111^{*}$ & $0.384 * *$ \\
& {$[0.056]$} & {$[0.178]$} \\
\hline Year Dummy & YES & YES \\
\hline Sector Dummy & YES & YES \\
\hline Country Dummy & YES & YES \\
\hline Observations & 872 & 494 \\
\hline Log Pseudo-likelihood & -296 & -449 \\
\hline Pseudo R2 & 0.1343 & 0.1311 \\
\hline \hline
\end{tabular}

Notes: In this table, the marginal effects of the regressors are reported. ***,**, and * indicate $1 \%, 5 \%$, and $10 \%$ significance, respectively. Figures in parentheses represent the White consistent standard error. In column (II), the sample is restricted to affiliates with positive exports to other ASEAN countries or China, affiliates in Singapore and Malaysia with positive exports to Japan, and affiliates in Thailand and Indonesia with positive exports to Japan in 2008. Furthermore, we drop affiliates who answered "importers are exempted from tariffs" as "reasons for not using FTAs."

There are three points that are noteworthy. First, as demonstrated in Demidova and Krishna (2008), the coefficient for Scale is estimated to be significantly positive, indicating that the larger the affiliate, the more likely it is to utilize an FTA scheme in its exporting. This result is also consistent with that in Takahashi and Urata $(2008,2009)$. Second, the coefficient for Concentration is estimated to be significantly negative, showing that benefits from the love-of-variety in inputs, and/or from vertical division of labor, exceed the rise in the administrative costs due to the diversity of procurement origins. In particular, it is interesting that firms which are actively engaged in international fragmentation are likely to use an FTA scheme in their exporting. Third, coefficients for export shares are all estimated to be positively significant and show an 
expected order in their magnitude. The largest magnitude can be found in the coefficient for ExCHINA, while the lowest magnitude in that for ExJAPAN. Thus, affiliates that export actively to countries with higher general tariffs are more likely to use FTAs. This result is consistent with what Kohpaiboon (2008) confirmed at the sector level.

The results of fixed effects in the estimation of column (I) might be worth reporting particularly for policy makers. Column (I) in Table 6 reports the results of country fixed effects. We find that affiliates in the Philippines and Vietnam are less likely to utilize FTA schemes, while the most active use of FTA is found in affiliates in Singapore. Due to the fact that Singapore provides the most efficient procedures for obtaining the COO, these results might suggest that such procedures in the Philippines and Vietnam are more cumbersome than those in other ASEAN countries. ${ }^{9}$ The results of sector fixed effects are reported in column (I) in Table 7. From this table, we can see that FTAs are less likely to be utilized in electric parts and components and precision machinery. This result is most likely due to the low general tariff rates in those sectors. Indeed, the general tariff rates for most IT products are low or zero under the Information Technology Agreement (ITA).

Table 6. Results of Country Dummy: Thailand as a Base

\begin{tabular}{|c|c|c|c|c|}
\hline & \multicolumn{2}{|c|}{ (I) } & \multicolumn{2}{|c|}{ (II) } \\
\hline & Coef. & $\begin{array}{l}\text { Robust } \\
\text { S.E. }\end{array}$ & Coef. & $\begin{array}{c}\text { Robust } \\
\text { S.E. }\end{array}$ \\
\hline Malaysia & 0.052 & {$[0.145]$} & 0.114 & [0.174] \\
\hline Singapore & $0.490 * *$ & [0.193] & 0.314 & [0.221] \\
\hline Indonesia & 0.026 & {$[0.161]$} & 0.15 & [0.202] \\
\hline Philippines & $-0.548 * * *$ & {$[0.160]$} & $-0.396^{*}$ & {$[0.220]$} \\
\hline Vietnam & $-0.670 * * *$ & {$[0.255]$} & -0.329 & [0.341] \\
\hline
\end{tabular}

Note: $* * *, * *$, and $*$ indicate $1 \%, 5 \%$, and $10 \%$ significance, respectively.

\footnotetext{
9 Also, this may reflect only the availability of FTA schemes for affiliates. Indeed, Singapore has concluded the largest number of FTAs among ASEAN countries, while there are relatively few FTAs in the Philippines and Vietnam compared with other ASEAN countries in the sample.
} 
Table 7. Results of Sector Dummy: Food Sector as a Base

\begin{tabular}{lccccc}
\hline \hline & \multicolumn{2}{c}{$(\mathrm{I})$} & & \multicolumn{2}{c}{ (II) } \\
\cline { 2 - 3 } \cline { 5 - 6 } & Coef. & Robust & & Coef. & Robust \\
& & S.E. & & & S.E. \\
\hline Wearing apparel & 0.641 & {$[0.440]$} & & 0.875 & {$[0.605]$} \\
Wood products & 0.125 & {$[0.470]$} & & 0.101 & {$[0.529]$} \\
Furniture & -0.954 & {$[0.626]$} & & & \\
Paper products & -0.308 & {$[0.563]$} & & 0.318 & {$[0.788]$} \\
Chemicals & -0.17 & {$[0.285]$} & & 0.108 & {$[0.313]$} \\
Petroleum products & 0.575 & {$[0.556]$} & & $1.090^{*}$ & {$[0.635]$} \\
Plastic products & -0.462 & {$[0.306]$} & & -0.192 & {$[0.344]$} \\
Rubber products & -0.232 & {$[0.347]$} & & -0.058 & {$[0.397]$} \\
Glass and glass products & -0.303 & {$[0.376]$} & & -0.312 & {$[0.419]$} \\
Basic iron and steel & -0.337 & {$[0.344]$} & & 0.073 & {$[0.382]$} \\
Non-ferrous metals & -0.139 & {$[0.326]$} & & 0.381 & {$[0.385]$} \\
Metal products & -0.369 & {$[0.290]$} & & -0.005 & {$[0.329]$} \\
General machinery & -0.368 & {$[0.342]$} & & 0.001 & {$[0.394]$} \\
Electric machinery & -0.363 & {$[0.278]$} & & -0.092 & {$[0.311]$} \\
Electric parts & $-0.938^{* * *}$ & {$[0.297]$} & & $-0.681^{* *}$ & {$[0.332]$} \\
Automobile & 0.646 & {$[0.425]$} & & $1.177^{* *}$ & {$[0.541]$} \\
Automobile parts & 0.314 & {$[0.276]$} & & $0.718^{* *}$ & {$[0.317]$} \\
Precision machinery & $-0.889^{*}$ & {$[0.524]$} & & -0.753 & {$[0.569]$} \\
Others & $-0.459^{*}$ & {$[0.271]$} & & -0.151 & {$[0.302]$} \\
\hline \hline
\end{tabular}

Note: $* * *, * *$, and $*$ show $1 \%, 5 \%$, and $10 \%$ significance, respectively.

We conduct one important robustness check. As mentioned before, affiliates should be excluded if they do not export to countries that conclude FTAs with their host countries. Here, we again pay attention only to three kinds of FTAs; AFTA, ASEAN-China FTA, and bilateral FTAs with Japan. Specifically, we restrict our sample only to affiliates with positive exports to other ASEAN countries or China. Furthermore, affiliates in Singapore and Malaysia are also included if they export to Japan. Affiliates in Thailand and Indonesia are not excluded if they have positive exports to Japan in $2008 .{ }^{10}$ We further

\footnotetext{
10 The reason for not using FTAs/EPAs, "there are no FTAs/EPAs with the countries to which we export", is available only in 2008. Since, unlike Section 2, our sample years include 2006 and 2007, we cannot use this information for restricting our sample to affiliates exporting to countries with FTAs with their host countries.
} 
take care of investment incentive schemes. As mentioned in Section 2, the major reason for not utilizing FTAs in ASEAN is that "importers are exempted from tariffs" (37.6\%). If affiliates' trading partners enjoy investment incentive schemes, such affiliates do not need to use FTAs in their exporting. Thus, such affiliates are dropped from our sample for the analysis of the exporters' choice of FTA use. To this end, we use the data item on "reasons for not using FTAs," and we drop affiliates that answered "tariffs are exempted in the importer side" for that item.

The result is reported in column (II). From Table 5, we can see that the results on our hypotheses remain unchanged. The results of fixed effects are reported in the corresponding columns in Tables 6 and 7. Two points are noteworthy here. First, there is the robust result that affiliates in the Philippines are less likely to use an FTA scheme. Second, coefficients for automobile sectors turn out to be significant. This change may indicate that active use of investment incentive schemes in ASEAN leads to the underestimation of the fixed effect's estimate in those sectors.

\section{Concluding Remarks}

It is noted that utilization of AFTA is low by international standards. In order to clarify the reasons for such low utilization, this paper investigates what kinds of Japanese affiliates in ASEAN are more likely to use FTAs in their exporting. For this purpose, we employ a unique dataset from a survey of Japanese affiliates operating in Asia conducted by the Japan External Trade Organization. Our findings are as follow. First, the larger the affiliate is, or the more diversified the origins of its procurements, the more likely it is to 
utilize an FTA scheme in its exporting. Second, affiliates that export actively to countries with higher general tariffs are more likely to use FTAs. Third, there are clear differences in FTA utilization depending affiliates' locations and sectors.

These results suggest some reasons why FTA utilization in East Asia is low by international standards. The first reason is the active use of investment incentive schemes in ASEAN. Enjoying such schemes, firms do not need to use FTA schemes in order to trade at zero tariff rates. The second is the fact that the major trade in ASEAN is in the electrical machinery industry, in which general tariff rates are already low. According to the World Trade Atlas database, in our six ASEAN countries, the share of electrical machinery exports to the world in total exports was near 30\% during 2006-2008. Almost the same share can also be observed in the case of imports. The last reason is the existence of fixed costs, for example the administrative costs due to the cumbersome procedures for obtaining a COO. The significant results in Scale and Concentration imply the existence of a certain level of such fixed costs. If fixed costs are high in ASEAN compared to other regions, this would constitute a reason for low utilization of FTAs. 


\section{References}

Arndt, S. W. and H. Kierzkowski (2001), "Fragmentation: New Production Patterns in the World Economy”. Oxford University Press, Oxford.

Baier, S.L. and Bergstrand, J.H. (2007), "Do Free Trade Agreements Actually Increase Members' International Trade?”, Journal of International Economics, 71(1): 72-95.

Demidova, S. and Krishna, K. (2008), "Firm Heterogeneity and Firm Behavior with Conditional Policies", Economics Letters, 98: 122-128.

Endoh, M. (1999), "Trade Creation and Trade Diversion in the EEC, the LAFTA and the CMEA: 1960-1994", Applied Economics, 31(2): 207-216.

Fukao, K. and Kwon, H. (2006), "Why Did Japan's Tfp Growth Slow Down in the Lost Decade? An Empirical Analysis Based on Firm-Level Data of Manufacturing Firms", Japanese Economic Review, 57(2): 195-228.

Hiratsuka, D., Isono, I., Sato, H., and Umezaki, S. (2008), "Escaping from FTA Trap and Spaghetti Bowl Problem in East Asia: An Insight from the Enterprise Survey in Japan, In: Soesastro, H. (Eds.)". Deepening Economic Integration in East Asia: The ASEAN Economic Community and Beyond, ERIA Research Project Report 2007 No. 1-2, Chapter 16.

James, W. (2006), "Rules of Origin in Emerging Asia-Pacific Preferential Trade Agreements: Will PTAs Promote Trade and Development", Asia-Pacific Research and Training Network on Trade Working Paper Series, No.19.

Kimura, F. (2006), "International Production and Distribution Networks in East Asia: Eighteen Facts, Mechanics, and Policy Implication", Asian Economic Policy Review, 1: 326-44.

Kohpaiboon, A. (2008), "Export Creation of AFTA and the Response of the Private Sector: Evidence from Thai Manufacturing”, mimeograph.

Melitz, M. (2003), “The Impact of Trade on Intraindustry Reallocations and Aggregate Industry Productivity", Econometrica, 71: 1695-1725.

Takahashi, K. and Urata, S. (2008), "On the Use of FTAs by Japanese Firms", RIETI Discussion Paper, 08-E-002.

Takahashi, K. and Urata, S. (2009), "On the Use of FTAs by Japanese Firms: Further Evidence", RIETI Discussion Paper, 09-E-028. 


\section{ERIA Discussion Paper Series}

\begin{tabular}{|c|c|c|c|}
\hline No. & Author(s) & Title & Year \\
\hline $2009-22$ & $\begin{array}{l}\text { Kazunobu HAYAKAWA, } \\
\text { Daisuke HIRATSUKA, } \\
\text { Kohei SHIINO, and } \\
\text { Seiya SUKEGAWA }\end{array}$ & Who Uses Free Trade Agreements? & $\begin{array}{l}\text { Nov } \\
2009\end{array}$ \\
\hline $2009-21$ & Ayako OBASHI & $\begin{array}{l}\text { Resiliency of Production Networks in Asia: } \\
\text { Evidence from the Asian Crisis }\end{array}$ & $\begin{array}{c}\text { Oct } \\
2009\end{array}$ \\
\hline $2009-20$ & $\begin{array}{l}\text { Mitsuyo ANDO and } \\
\text { Fukunari KIMURA }\end{array}$ & Fragmentation in East Asia: Further Evidence & $\begin{array}{c}\text { Oct } \\
2009\end{array}$ \\
\hline $2009-19$ & Xunpeng SHI & $\begin{array}{l}\text { The Prospects for Coal: } \\
\text { Global Experience and Implications for Energy Policy }\end{array}$ & $\begin{array}{l}\text { Sept } \\
2009\end{array}$ \\
\hline $2009-18$ & Sothea OUM & $\begin{array}{l}\text { Income Distribution and Poverty in a CGE } \\
\text { Framework: A Proposed Methodology }\end{array}$ & $\begin{array}{c}\text { Jun } \\
2009\end{array}$ \\
\hline $2009-17$ & $\begin{array}{l}\text { Erlinda M. MEDALLA } \\
\text { and Jenny BALBOA }\end{array}$ & $\begin{array}{l}\text { ASEAN Rules of Origin: } \\
\text { Lessons and Recommendations for the Best Practice }\end{array}$ & $\begin{array}{c}\text { Jun } \\
2009\end{array}$ \\
\hline $2009-16$ & Masami ISHIDA & Special Economic Zones and Economic Corridors & $\begin{array}{c}\text { Jun } \\
2009\end{array}$ \\
\hline $2009-15$ & Toshihiro KUDO & $\begin{array}{l}\text { Border Area Development in the GMS: } \\
\text { Turning the Periphery into the Center of Growth }\end{array}$ & $\begin{array}{l}\text { May } \\
2009\end{array}$ \\
\hline $2009-14$ & $\begin{array}{l}\text { Claire HOLLWEG and } \\
\text { Marn-Heong WONG }\end{array}$ & $\begin{array}{l}\text { Measuring Regulatory Restrictions in Logistics } \\
\text { Services }\end{array}$ & $\begin{array}{l}\text { Apr } \\
2009\end{array}$ \\
\hline $2009-13$ & Loreli C. De DIOS & Business View on Trade Facilitation & $\begin{array}{l}\text { Apr } \\
2009\end{array}$ \\
\hline $2009-12$ & $\begin{array}{l}\text { Patricia SOURDIN and } \\
\text { Richard POMFRET }\end{array}$ & Monitoring Trade Costs in Southeast Asia & $\begin{array}{l}\text { Apr } \\
2009\end{array}$ \\
\hline 2009-11 & $\begin{array}{l}\text { Philippa DEE and } \\
\text { Huong DINH }\end{array}$ & $\begin{array}{l}\text { Barriers to Trade in Health and Financial Services in } \\
\text { ASEAN }\end{array}$ & $\begin{array}{l}\text { Apr } \\
2009\end{array}$ \\
\hline $2009-10$ & Sayuri SHIRAI & $\begin{array}{l}\text { The Impact of the US Subprime Mortgage Crisis on } \\
\text { the World and East Asia: Through Analyses of } \\
\text { Cross-border Capital Movements }\end{array}$ & $\begin{array}{c}\text { Apr } \\
2009\end{array}$ \\
\hline 2009-09 & $\begin{array}{l}\text { Mitsuyo ANDO and } \\
\text { Akie IRIYAMA }\end{array}$ & $\begin{array}{l}\text { International Production Networks and Export/Import } \\
\text { Responsiveness to Exchange Rates: } \\
\text { The Case of Japanese Manufacturing Firms }\end{array}$ & $\begin{array}{l}\text { Mar } \\
2009\end{array}$ \\
\hline
\end{tabular}




\begin{tabular}{|c|c|c|c|}
\hline 2009-08 & Archanun KOHPAIBOON & $\begin{array}{l}\text { Vertical and Horizontal FDI Technology Spillovers: } \\
\text { Evidence from Thai Manufacturing }\end{array}$ & $\begin{array}{c}\text { Mar } \\
2009\end{array}$ \\
\hline 2009-07 & $\begin{array}{l}\text { Kazunobu HAYAKAWA, } \\
\text { Fukunari KIMURA, and } \\
\text { Toshiyuki MATSUURA }\end{array}$ & $\begin{array}{l}\text { Gains from Fragmentation at the Firm Level: } \\
\text { Evidence from Japanese Multinationals in East Asia }\end{array}$ & $\begin{array}{c}\text { Mar } \\
2009\end{array}$ \\
\hline $2009-06$ & Dionisius A. NARJOKO & $\begin{array}{l}\text { Plant Entry in a More Liberalised Industrialisation } \\
\text { Process: An Experience of Indonesian Manufacturing } \\
\text { during the } 1990 \mathrm{~s}\end{array}$ & $\begin{array}{l}\text { Mar } \\
2009\end{array}$ \\
\hline $2009-05$ & $\begin{array}{l}\text { Kazunobu HAYAKAWA, } \\
\text { Fukunari KIMURA, and } \\
\text { Tomohiro MACHIKITA }\end{array}$ & Firm-level Analysis of Globalization: A Survey & $\begin{array}{l}\text { Mar } \\
2009\end{array}$ \\
\hline 2009-04 & $\begin{array}{l}\text { Chin Hee HAHN and } \\
\text { Chang-Gyun PARK }\end{array}$ & $\begin{array}{l}\text { Learning-by-exporting in Korean Manufacturing: } \\
\text { A Plant-level Analysis }\end{array}$ & $\begin{array}{l}\text { Mar } \\
2009\end{array}$ \\
\hline $2009-03$ & Ayako OBASHI & $\begin{array}{l}\text { Stability of Production Networks in East Asia: } \\
\text { Duration and Survival of Trade }\end{array}$ & $\begin{array}{l}\text { Mar } \\
2009\end{array}$ \\
\hline 2009-02 & Fukunari KIMURA & $\begin{array}{l}\text { The Spatial Structure of Production/Distribution } \\
\text { Networks and Its Implication for Technology } \\
\text { Transfers and Spillovers }\end{array}$ & $\begin{array}{l}\text { Mar } \\
2009\end{array}$ \\
\hline 2009-01 & $\begin{array}{l}\text { Fukunari KIMURA and } \\
\text { Ayako OBASHI }\end{array}$ & $\begin{array}{l}\text { International Production Networks: } \\
\text { Comparison between China and ASEAN }\end{array}$ & $\begin{array}{c}\text { Jan } \\
2009\end{array}$ \\
\hline $2008-03$ & $\begin{array}{l}\text { Kazunobu HAYAKAWA } \\
\text { and Fukunari KIMURA }\end{array}$ & $\begin{array}{l}\text { The Effect of Exchange Rate Volatility on } \\
\text { International Trade in East Asia }\end{array}$ & $\begin{array}{l}\text { Dec } \\
2008\end{array}$ \\
\hline $2008-02$ & $\begin{array}{l}\text { Satoru KUMAGAI, } \\
\text { Toshitaka GOKAN, } \\
\text { Ikumo ISONO, and } \\
\text { Souknilanh KEOLA }\end{array}$ & $\begin{array}{l}\text { Predicting Long-Term Effects of Infrastructure } \\
\text { Development Projects in Continental South East Asia: } \\
\text { IDE Geographical Simulation Model }\end{array}$ & $\begin{array}{l}\text { Dec } \\
2008\end{array}$ \\
\hline 2008-01 & $\begin{array}{l}\text { Kazunobu HAYAKAWA, } \\
\text { Fukunari KIMURA, and } \\
\text { Tomohiro MACHIKITA }\end{array}$ & Firm-level Analysis of Globalization: A Survey & $\begin{array}{l}\text { Dec } \\
2008\end{array}$ \\
\hline
\end{tabular}

